\title{
Article \\ Synthesis, Spectroscopic, Thermal, and Catalytic Properties of Eight New Complexes of Metal(II) Formates or Propionates with Imidazole; Relationship between the Carbon Chain Length and Catalytic Activity
}

\author{
Bartłomiej Rogalewicz *, Tomasz Maniecki, Radosław Ciesielski and Agnieszka Czylkowska *(D) \\ Institute of General and Ecological Chemistry, Faculty of Chemistry, Lodz University of Technology, \\ Zeromskiego 116, 90-924 Lodz, Poland; tomasz.maniecki@p.lodz.pl (T.M.); radoslaw.ciesielski@p.lodz.pl (R.C.) \\ * Correspondence: bartlomiej.rogalewicz@dokt.p.lodz.pl (B.R.); agnieszka.czylkowska@p.lodz.pl (A.C.)
}

Citation: Rogalewicz, B.; Maniecki,

T.; Ciesielski, R.; Czylkowska, A.

Synthesis, Spectroscopic, Thermal, and Catalytic Properties of Eight New Complexes of Metal(II)

Formates or Propionates with Imidazole; Relationship between the Carbon Chain Length and Catalytic Activity. Materials 2022, 15, 142. https://doi.org/10.3390/ ma15010142

Academic Editor: Nicola Margiotta

Received: 7 November 2021

Accepted: 16 December 2021

Published: 25 December 2021

Publisher's Note: MDPI stays neutral with regard to jurisdictional claims in published maps and institutional affiliations.

Copyright: (C) 2021 by the authors. Licensee MDPI, Basel, Switzerland. This article is an open access article distributed under the terms and conditions of the Creative Commons Attribution (CC BY) license (https:// creativecommons.org/licenses/by/ $4.0 /)$.

\begin{abstract}
In one of our previously published articles, we reported the synthesis, spectroscopic, thermal, and catalytic properties of four new $\mathrm{M}(\mathrm{II})$ acetate (where $\mathrm{M}=\mathrm{Co}, \mathrm{Ni}, \mathrm{Cu}, \mathrm{Zn}$ ) complexes with imidazole. Presented compounds exhibited activity in the reaction on catalytic oxidation of styrene. In this study we have synthesized and investigated properties of analogous compounds, however using formates or propionates of mentioned metal cations instead of acetates. Such an approach allowed us to draw valuable conclusions concerning the relationship between the carbon chain length and catalytic activity, which is an important factor for catalyst modeling. Synthesized compounds have been thoroughly investigated using appropriate analytic techniques: AAS (Atomic Absorption Spectrometry), FTIR (Fourier-Transform Infrared Spectroscopy), and TGA (Thermogravimetric Analysis). Catalytic properties have been studied under the same previous conditions, using GC-FID (GC-chromatograph equipped with FID detector).
\end{abstract}

Keywords: metal(II) complexes; imidazole; formates; propionates; TG-DTG; FTIR; catalyst; styrene oxidation

\section{Introduction}

Incorporation of different ligands or counterions can significantly change physicochemical or biological properties of metal-based coordination compounds. One of the most popular ligands is imidazole. Imidazole and its derivatives are also known for their valuable properties, e.g., antifungal, antibacterial, anti-inflammatory, antiviral, and anticancer [1-7]. Imidazole itself is also a part of biologically important systems, e.g., one of the amino acids-histidine. Enormous variety of possible connections of different metal centres and compounds exhibiting useful properties or their derivatives create great opportunity to obtain outstanding results. It is thus important to determine the relationship between structure and activity, which is currently one of the most promising strategies in new drugs and catalyst design. All four mentioned metals, cobalt [8-11], nickel [12-14], copper [15-17], and zinc [17-19] are crucial and widely used in catalysis. One of the important reactions, problematic from an industrial point of view, is the reaction of the oxidation of styrene. This reaction is usually carried out in the presence of peracids however, since it leads to obtaining undesirable products, an ecological oxidizer $\left(\mathrm{H}_{2} \mathrm{O}_{2}\right)$ can be used instead. In order to ensure proper conversion, a catalyst has to be used. Some catalysts have already been tested, like chromium-silica systems-resulting in obtaining benzaldehyde as the main product [20] or molecular sieves - in this case the main product was phenylacetaldehyde [21]. Benzaldehyde was also obtained in many other cases. Some examples comprise of modified cobalt or zinc oxide catalysts [22,23], as well as copper(II) complexes [24].

In one our previously published articles, we reported the synthesis, spectroscopic, thermal, and catalytic properties of four new $\mathrm{M}(\mathrm{II})$ acetate (where $\mathrm{M}=\mathrm{Co}, \mathrm{Ni}, \mathrm{Cu}, \mathrm{Zn}$ ) 
complexes with imidazole [25]. Apart from experimental methods, such compounds can also be studied using computational techniques [26-28]. After physicochemical characterisation, synthesized compounds have additionally been tested for catalytic activity in a styrene oxidation reaction. Performed tests have given promising results with good percentage styrene conversion and almost $100 \%$ selectivity towards carbon dioxide formation. This is an important fact since one of the possible, undesired products for this reaction is benzaldehyde. In this paper, we report the synthesis and study of the physicochemical properties of analogous compounds, however using the formates or propionates of mentioned metal cations instead of acetates. Such an approach allows us to draw some valuable conclusions about the relationship between the carbon chain length and catalytic activity of investigated compounds, as well as thoroughly investigate their properties. (Abbreviations: $\mathrm{L}_{1}$ - formate anion; $\mathrm{Ac}$-acetate anion; $\mathrm{L}_{2}$ - propionate anion; $\mathrm{Im}$-imidazole; $\mathrm{Im}_{\mathrm{d}}$-deprotonated imidazole)

\section{Materials and Methods}

All chemicals that were used for the synthesis were purchased from the following companies: Sigma-Aldrich, Pol-Aura, and Avantor Performance Materials Poland and were used without further purification. The contents of $\mathrm{Co}(\mathrm{II}), \mathrm{Ni}(\mathrm{II}), \mathrm{Cu}(\mathrm{II})$, and $\mathrm{Zn}(\mathrm{II})$ ions were determined by Atomic Absorption Spectrometry. Standard solutions from Merck (1000 mg/L, Darmstadt, Germany) were used for the preparation of diluted solutions used for calibration. For analysis, distilled water (electrical conductivity $0.05 \mu \mathrm{S}$ ) was used (obtained with Polwater system). Infrared spectra were recorded using IRTracer100 Schimadzu Spectrometer (Japan) (3200-600 cm $\mathrm{cm}^{-1}$, accuracy of recording: $1 \mathrm{~cm}^{-1}$ ) in potassium bromide pellets. Thermal decompositions of compounds were studied using the TG-DTG thermogravimetric technique (range of temperature $25-800{ }^{\circ} \mathrm{C}$; heating rate: $10{ }^{\circ} \mathrm{C} \cdot \mathrm{min}^{-1}$ ). TG and DTG curves were recorded using Netzsch TG 209 (Germany), in ceramic crucibles, under air atmosphere, $\mathrm{v}=20 \mathrm{~mL} \cdot \mathrm{min}^{-1}$. As a reference material, ceramic crucibles were used. Catalytic properties have been studied in the liquid-phase styrene oxidation reaction. Reactions were carried out in $50-\mathrm{mL}$ round-bottom flasks with the molar ratio of reagents being the same as in the previous part of the study [25]: $\mathrm{C}_{2} \mathrm{H}_{3} \mathrm{~N}: \mathrm{H}_{2} \mathrm{O}_{2}: \mathrm{C}_{8} \mathrm{H}_{8}=1: 1: 1$. The reaction mixture was stirred in a water bath at $60{ }^{\circ} \mathrm{C}$ and refluxed. After reaching this temperature, $10 \mathrm{mg}$ of the catalyst was added. The optimum time of reaction for obtaining reliable results was found to be $2 \mathrm{~h}$. After that time, the analysis of styrene content was performed using gas chromatography with a flame ionization detector (GC-FID, HP 5890, Hewlett Packard Corporation, (USA). The optimal parameters of method found for our study were as follows: Separation column: ZB-FFAP capillary column $(30 \mathrm{~m} \times 0.25 \mathrm{~mm} \times 0.25 \mu \mathrm{m})$ with oven parameters: $60^{\circ} \mathrm{C}$ for $8 \mathrm{~min}$ to $150{ }^{\circ} \mathrm{C} / \mathrm{min}$ for $4 \mathrm{~min}$; injection temperature of $225^{\circ} \mathrm{C}$; injection split: 11:8:1, $0.5 \mu \mathrm{L}$; and detector temperature of $250{ }^{\circ} \mathrm{C}$. A carrier gas helium was used with a flow of $3.4 \mathrm{~mL} / \mathrm{min}$. As previously done, conversion degrees were determined according to the formula below:

$$
\text { Conversion }=\left[\frac{\mathrm{A}_{0}-\mathrm{A}_{\mathrm{t}}}{\mathrm{A}_{0}}\right] \times 100 \%
$$

where: $A_{0}$ is the initial styrene concentration in reactant mixture and $A_{t}$ is the concentration of styrene after $2 \mathrm{~h}$ of the reaction.

\subsection{Synthesis of M(II) Formates and Propionates}

$\mathrm{M}$ (II) formates and propionates for synthesis were prepared using concentrated formic and propionic acids. Mixtures of appropriate acid and basic M(II) carbonate have been heated, refluxed, and stirred for $5 \mathrm{~h}$. After that time, the excess of the unreacted carbonates was filtered. Filtrates were cooled and left for several days for crystallization. Obtained crystals were filtered and ground in a mortar. The purity of synthesized compounds was proven with thermogravimetric analysis. It also allowed establishing the amount of water 
molecules in hydrated compounds. Synthesis of M(II) formates and propionates is shown in Figure 1.

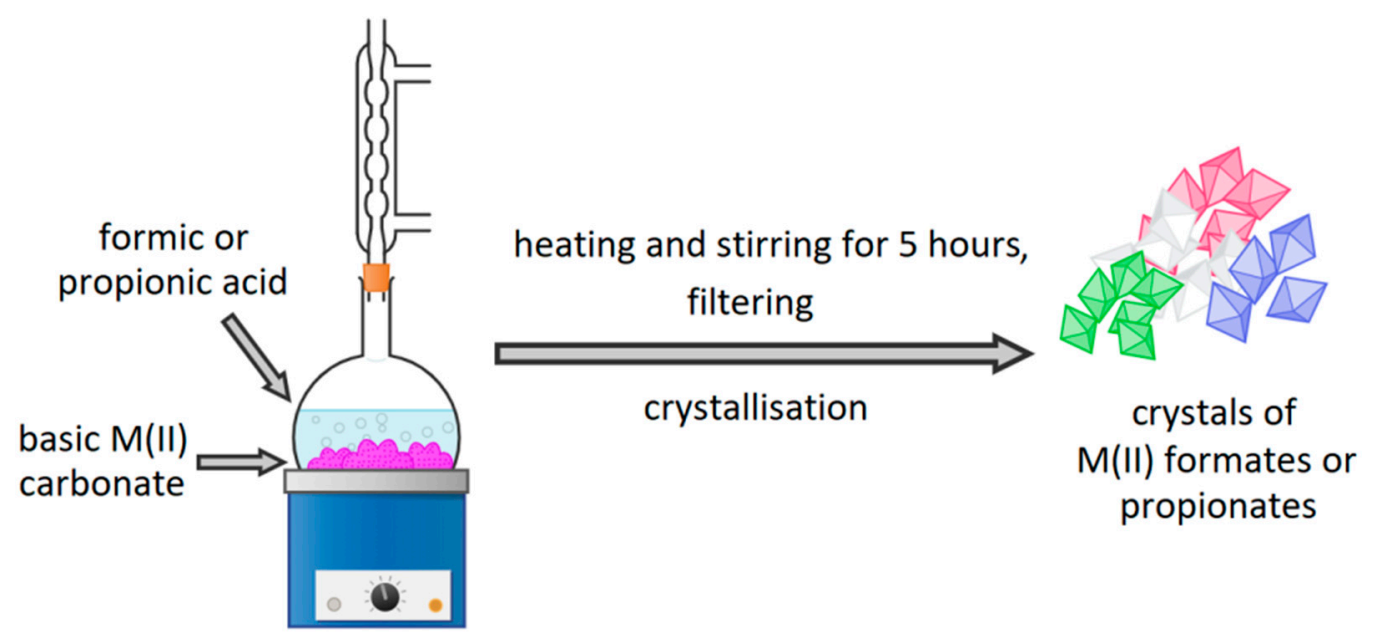

Figure 1. Synthesis of appropriate M(II) formates and propionates.

\subsection{Synthesis of M(II) Formate and Propionate Complexes with Imidazole}

In the next step, complexes of M(II) formates and propionates with imidazole were synthesized. Appropriate M(II) formate or propionate was dissolved in distilled water and mixed with an ethanol solution of imidazole. Reaction mixtures were heated to $30{ }^{\circ} \mathrm{C}$ and stirred for $3 \mathrm{~h}$. The volume of the reaction mixture did not exceed $60 \mathrm{~mL}$. Figure 2 presents a synthesis of the described complexes.

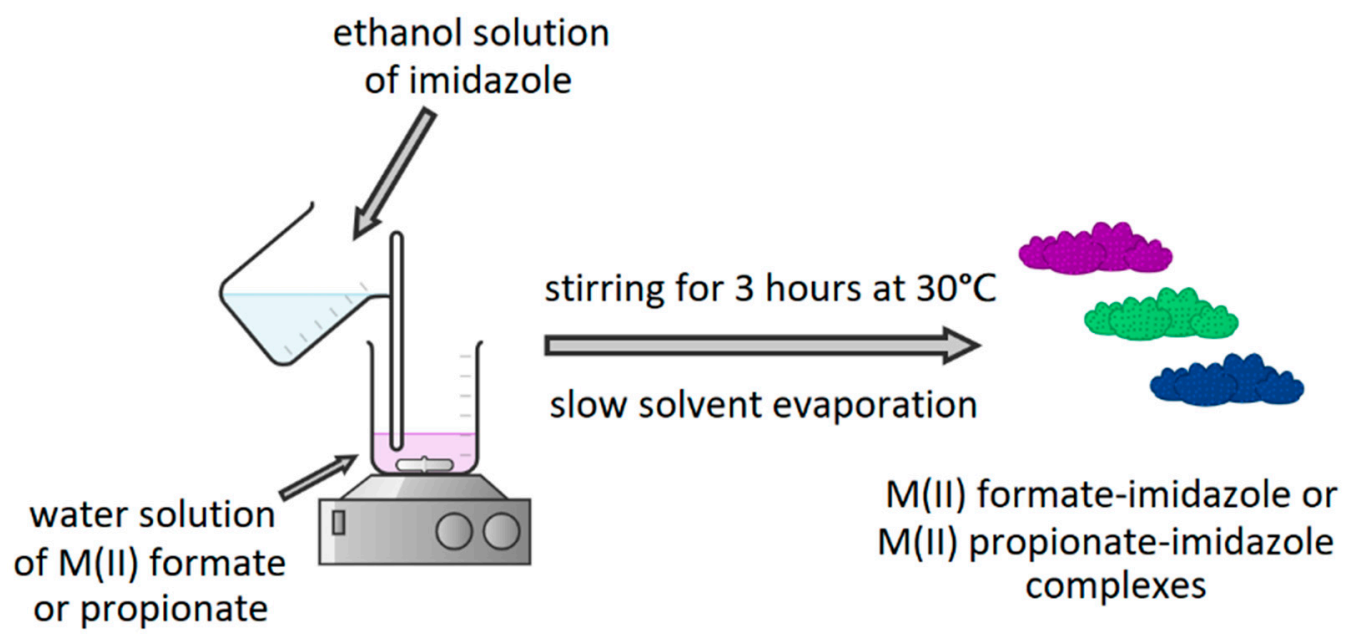

Figure 2. Synthesis of M(II) formate-imidazole or M(II) propionate-imidazole complexes.

The molar ratio of metal cation and imidazole was determined based on the formulas of the complexes synthesized in our previous study [25]. This data is presented in Table 1.

Table 1. Formulas of the synthesized M(II) formate and propionate complexes with imidazole and previously synthesized M(II) acetate complexes with imidazole [25].

\begin{tabular}{ccc}
\hline $\mathrm{Co}\left(\mathrm{L}_{1}\right)_{2}(\mathrm{Im}) \cdot \mathrm{H}_{2} \mathrm{O}$ & $\mathrm{Co}(\mathrm{Ac})_{2}(\mathrm{Im}) \cdot \mathrm{H}_{2} \mathrm{O}$ & $\mathrm{Co}\left(\mathrm{L}_{2}\right)_{2}(\mathrm{Im}) \cdot \mathrm{H}_{2} \mathrm{O}$ \\
\hline $\mathrm{Ni}\left(\mathrm{L}_{1}\right)_{2}(\mathrm{Im})_{1.5} \cdot \mathrm{H}_{2} \mathrm{O}$ & $\mathrm{Ni}(\mathrm{Ac})_{2}(\mathrm{Im})_{1,5} \cdot 2 \mathrm{H}_{2} \mathrm{O}$ & $\mathrm{Ni}\left(\mathrm{L}_{2}\right)_{2}(\operatorname{Im})_{1,5} \cdot \mathrm{H}_{2} \mathrm{O}$ \\
\hline $\mathrm{Cu}\left(\mathrm{L}_{1}\right)_{2}(\mathrm{Im})_{0.5} \cdot 0.5 \mathrm{H}_{2} \mathrm{O}$ & $\mathrm{Cu}_{2}(\mathrm{Ac})_{4}(\mathrm{Im})$ & $\mathrm{Cu}\left(\mathrm{L}_{2}\right)\left(\mathrm{Im}_{\mathrm{d}}\right)$ \\
\hline $\mathrm{Zn}\left(\mathrm{L}_{1}\right)_{2}(\mathrm{Im}) \cdot \mathrm{H}_{2} \mathrm{O}$ & $\mathrm{Zn}(\mathrm{Ac})_{2}(\mathrm{Im}) \cdot \mathrm{H}_{2} \mathrm{O}$ & $\mathrm{Zn}\left(\mathrm{L}_{2}\right)_{2}(\mathrm{Im}) \cdot \mathrm{H}_{2} \mathrm{O}$ \\
\hline
\end{tabular}


After $3 \mathrm{~h}$ of stirring, clear reaction mixtures were left for slow solvent evaporation. In the case of $\mathrm{Cu}$ (II) propionate-imidazole synthesis, the complex precipitated immediately after adding the imidazole solution. As a result, the molar ratio of $\mathrm{Cu}$ (II) and imidazole is in this case different than previously assumed. After $3 \mathrm{~h}$, the precipitate was filtered and washed several times with distilled water. In the next step, the formulas of all synthesized complexes were established and their properties were investigated.

\section{Results and Discussion}

\subsection{Atomic Absorption Spectrometry}

This technique allowed us to determine the contents of metal cations in investigated compounds, which confirms obtaining the compounds that are described by the presented formulas. Table 2 presents measured values in comparison with theoretical ones.

Table 2. Measured and theoretical percentage M(II) contents for investigated compounds.

\begin{tabular}{ccc}
\hline \multirow{2}{*}{ Compound } & \multicolumn{2}{c}{ M(II) Content [\%] } \\
\cline { 2 - 3 } & Measured & Theoretical \\
\hline $\mathrm{Co}\left(\mathrm{L}_{1}\right)_{2}(\mathrm{Im}) \cdot \mathrm{H}_{2} \mathrm{O}$ & 25.26 & 25.07 \\
\hline $\mathrm{Ni}\left(\mathrm{L}_{1}\right)_{2}(\mathrm{Im})_{1.5} \cdot \mathrm{H}_{2} \mathrm{O}$ & 21.66 & 21.83 \\
\hline $\mathrm{Cu}\left(\mathrm{L}_{1}\right)_{2}(\mathrm{Im})_{0.5} \cdot 0.5 \mathrm{H}_{2} \mathrm{O}$ & 32.60 & 32.32 \\
\hline $\mathrm{Zn}\left(\mathrm{L}_{1}\right)_{2}(\mathrm{Im}) \cdot \mathrm{H}_{2} \mathrm{O}$ & 27.19 & 27.07 \\
\hline $\mathrm{Co}\left(\mathrm{L}_{2}\right)_{2}(\mathrm{Im}) \cdot \mathrm{H}_{2} \mathrm{O}$ & 20.09 & 20.24 \\
\hline $\mathrm{Ni}\left(\mathrm{L}_{2}\right)_{2}(\mathrm{Im})_{1.5} \cdot \mathrm{H}_{2} \mathrm{O}$ & 19.01 & 18.06 \\
\hline $\mathrm{Cu}\left(\mathrm{L}_{2}\right)(\mathrm{Im})_{\mathrm{d}}$ & 32.14 & 31.05 \\
\hline $\mathrm{Zn}\left(\mathrm{L}_{2}\right)_{2}(\mathrm{Im}) \cdot \mathrm{H}_{2} \mathrm{O}$ & 22.07 & 21.97 \\
\hline
\end{tabular}

\subsection{FTIR Spectra}

The FTIR spectra of synthesized complexes prove their purity and allow establishing the manner in which carboxylate anions and imidazole bind the metal cation. All analyses have been performed in a manner analogous to the previously studied compounds [25].

Figures 3 and 4 present the FTIR spectra of M(II) formate-imidazole and M(II) propionateimidazole complexes, respectively. The FTIR spectra of sodium formate and sodium propionate have also been added in order to determine how formate and propionate anions coordinate metal centres, according to the spectroscopic criteria described by Nakamoto [29] and Alcock and co-authors [30].

The most important modes observed for studied complexes, sodium formate, and sodium propionate are presented in Table 3.

Stretching $v(\mathrm{NH})$ bands can be found in the range $3139-3037 \mathrm{~cm}^{-1}$. It is important to notice that these bands are not observed in the $\mathrm{Cu}\left(\mathrm{L}_{2}\right)(\mathrm{Im})_{\mathrm{d}}$ spectrum, which is a proof of deprotonation of the $\mathrm{NH}$ group in the imidazole molecule for this compound. Stretching $(\mathrm{CH})_{\text {alifat. }}$ bands can be found in their characteristic area, $2973-2826 \mathrm{~cm}^{-1}$. In the region, $955-746 \mathrm{~cm}^{-1}$, we can observe a characteristic band that can be ascribed to $\pi(\mathrm{CH})$ and $\delta$ (imidazole ring) vibrations. Recognizing the $v(\mathrm{COO})_{\text {as. }}$ and $v(\mathrm{COO})_{\text {sym. }}$ bands allowed us to calculate $\Delta v(\mathrm{COO})$ values, according to the formula: $\Delta v(\mathrm{COO})=v(\mathrm{COO})_{\text {as }}-v(\mathrm{COO})_{\text {sym }}$. Based on spectroscopic criteria. Nakamoto [29], Alcock and co-authors [30] compared values of separation of $v(\mathrm{COO})_{\text {as. }}$. And $v(\mathrm{COO})_{\text {sym. frequencies of studied compounds }}$ with analogous bands found in the spectra of appropriate carboxylate sodium salts. The $\Delta v(\mathrm{COO})$ values characterize the nature of metal-carboxylate bond. When $\Delta v_{\mathrm{Na}}>\Delta v_{\text {complex }}$ the carboxylate group is considered to be a bidentate chelating ligand, in case of $\Delta v_{\mathrm{Na}}$ $<\Delta v_{\text {complex }}$, it coordinates as monodentate ligand and for $\Delta v_{\mathrm{Na}} \approx \Delta v_{\text {complex }}$, it acts as a bidentate-bridging donor [29,30]. On this basis, we can say that in the case of $\mathrm{Co}\left(\mathrm{L}_{1}\right)_{2}(\mathrm{Im}) \cdot \mathrm{H}_{2} \mathrm{O}, \mathrm{Ni}\left(\mathrm{L}_{1}\right)_{2}(\operatorname{Im})_{1.5} \cdot \mathrm{H}_{2} \mathrm{O}, \mathrm{Cu}\left(\mathrm{L}_{1}\right)_{2}(\operatorname{Im})_{0.5} \cdot 0.5 \mathrm{H}_{2} \mathrm{O}, \mathrm{Co}\left(\mathrm{L}_{2}\right)_{2}(\mathrm{Im}) \cdot \mathrm{H}_{2} \mathrm{O}, \mathrm{Cu}\left(\mathrm{L}_{2}\right)(\operatorname{Im})_{\mathrm{d}}$, 
and $\mathrm{Zn}\left(\mathrm{L}_{2}\right)_{2}(\mathrm{Im}) \cdot \mathrm{H}_{2} \mathrm{O}$ compounds, the carboxylate groups bind the metal centres in a bidentatebridging manner. In the case of $\mathrm{Zn}\left(\mathrm{L}_{1}\right)_{2}(\mathrm{Im}) \cdot \mathrm{H}_{2} \mathrm{O}$, we can find both higher and lower band separation values in comparison with sodium salt, which indicates two ways of binding the zinc cation: monodentate and bidentate-chelating. Analyzed values suggest the monodentate way of binding in the case of the $\mathrm{Ni}\left(\mathrm{L}_{2}\right)_{2}(\mathrm{Im})_{1.5} \cdot \mathrm{H}_{2} \mathrm{O}$ compound.

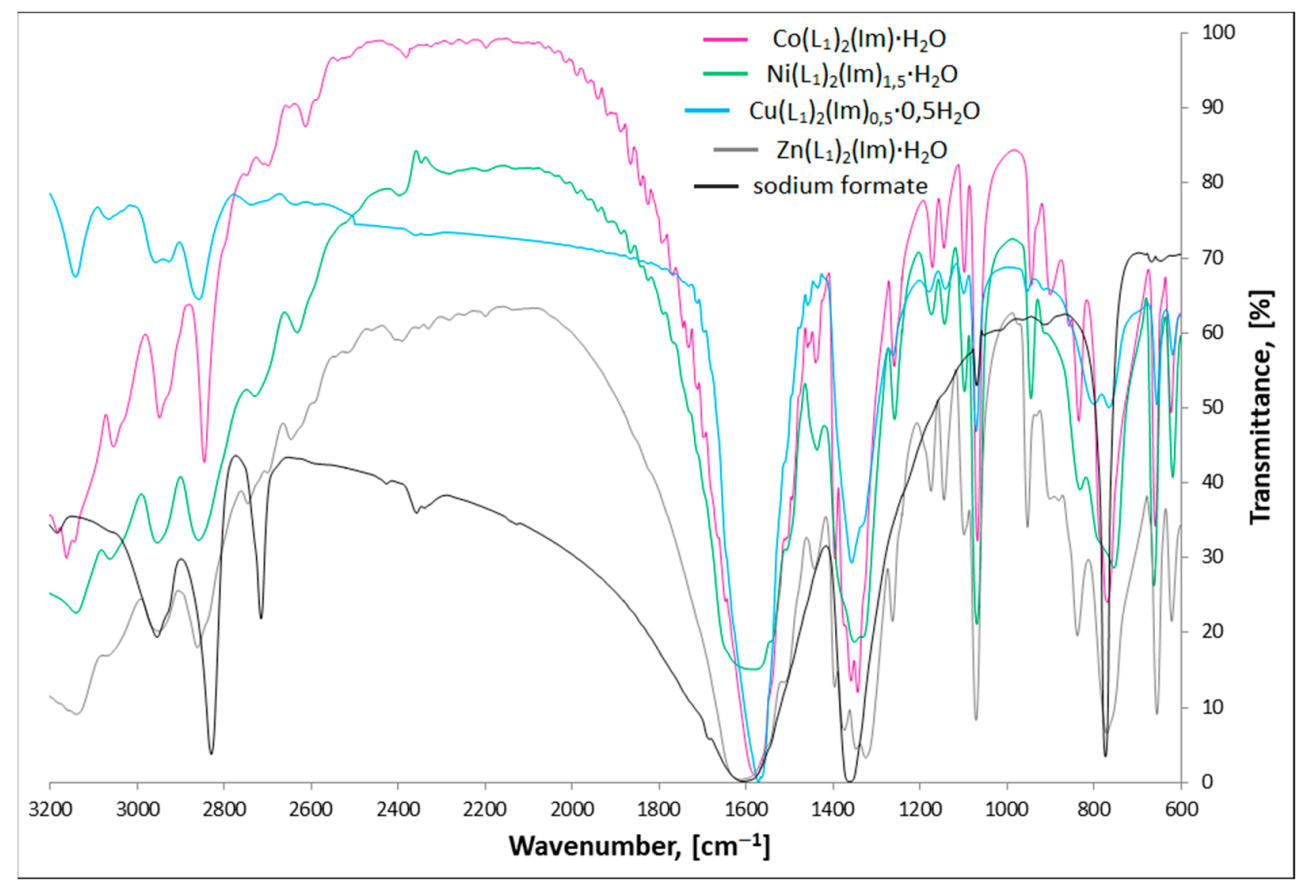

Figure 3. FTIR spectra of studied M(II) formate-imidazole complexes and sodium formate.

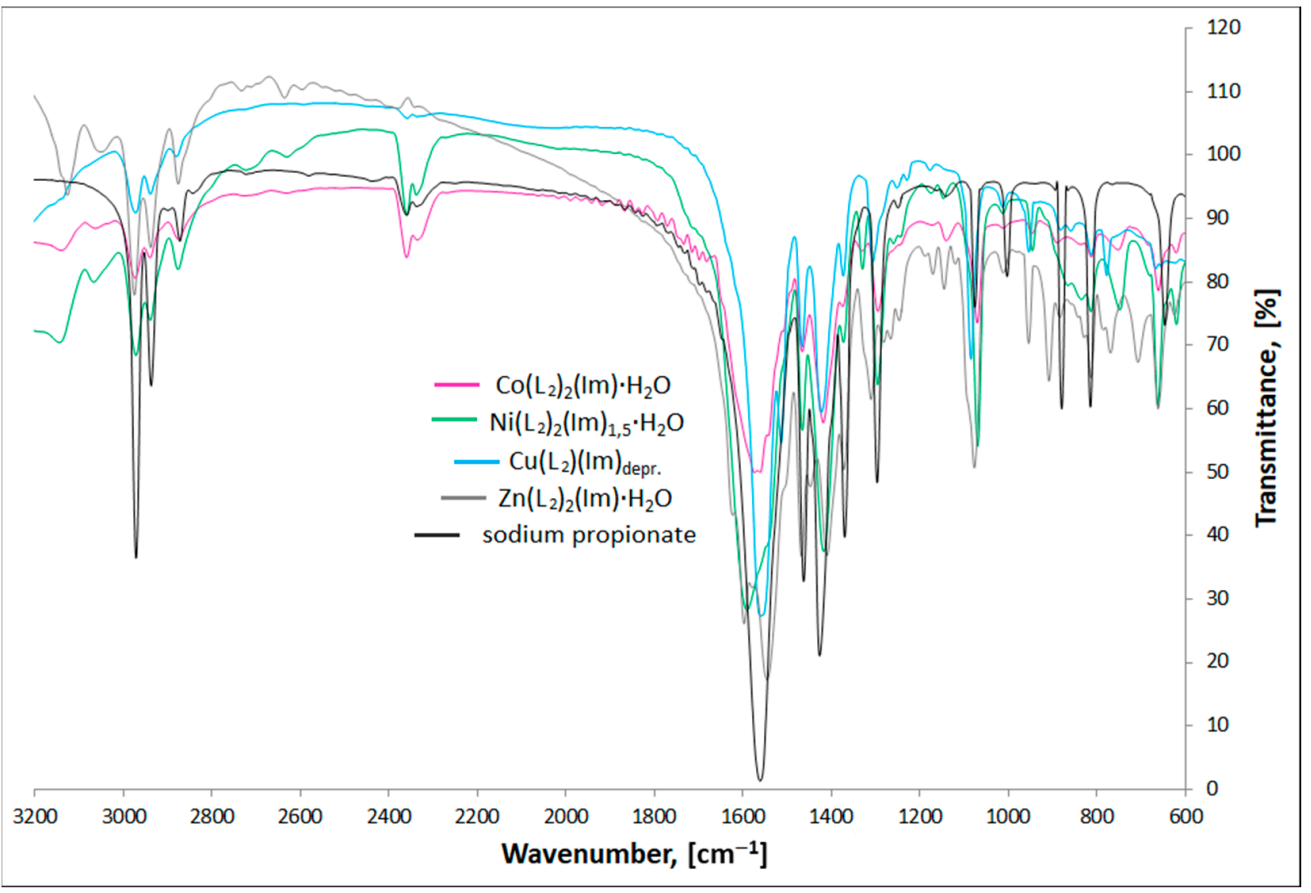

Figure 4. FTIR spectra of studied M(II) propionate-imidazole complexes and sodium propionate. 
Table 3. FTIR modes $\left(\mathrm{cm}^{-1}\right)$ observed for studied M(II) formate- or propionate-imidazole complexes, and for sodium formate and sodium propionate.

\begin{tabular}{|c|c|c|c|c|c|c|}
\hline & $v(\mathrm{NH})$ & $v(\mathrm{CH})_{\text {aliphat. }}$ & $\begin{array}{c}\pi(\mathrm{CH}), \delta(\text { Imidazole } \\
\text { Ring) }\end{array}$ & $v(\mathrm{COO})_{\mathrm{as}}$ & $v(\mathrm{COO})_{\mathrm{sym}}$ & $\Delta v(\mathrm{COO})$ \\
\hline Sodium formate & - & 2946,2826 & - & 1585 & 1350 & 235 \\
\hline $\mathrm{Co}\left(\mathrm{L}_{1}\right)_{2}(\mathrm{Im}) \cdot \mathrm{H}_{2} \mathrm{O}$ & 3158,3139 & 2942,2843 & $943,884,834,767$ & 1570 & 1339,1324 & 231,246 \\
\hline $\mathrm{Ni}\left(\mathrm{L}_{1}\right)_{2}(\mathrm{Im})_{1.5} \cdot \mathrm{H}_{2} \mathrm{O}$ & 3129 & 2939,2845 & $943,825,765$ & 1571 & 1331 & 240 \\
\hline $\mathrm{Cu}\left(\mathrm{L}_{1}\right)_{2}(\mathrm{Im})_{0.5} \cdot 0.5 \mathrm{H}_{2} \mathrm{O}$ & 3135 & $2939,2917,2849$ & $951,794,759$ & 1572 & 1351 & 221 \\
\hline $\mathrm{Zn}\left(\mathrm{L}_{1}\right)_{2}(\mathrm{Im}) \cdot \mathrm{H}_{2} \mathrm{O}$ & 3126 & 2941,2854 & $955,887,935,768$ & 1605 & $1386,1355,1328,1317$ & $219,250,277,288$ \\
\hline Sodium propoionate & - & $2973,2939,2869$ & - & 1565 & 1461,1424 & 89,141 \\
\hline $\mathrm{Co}\left(\mathrm{L}_{2}\right)_{2}(\mathrm{Im}) \cdot \mathrm{H}_{2} \mathrm{O}$ & 3127 & $2970,2934,2868$ & $943,899,822,811,746$ & 1566 & 1476,1415 & 90,151 \\
\hline $\mathrm{Ni}\left(\mathrm{L}_{2}\right)_{2}(\mathrm{Im})_{1.5} \cdot \mathrm{H}_{2} \mathrm{O}$ & 3136,3055 & $2969,2936,2871$ & $944,852,819,812,746$ & 1584 & 1464,1414 & 120,170 \\
\hline $\mathrm{Cu}\left(\mathrm{L}_{2}\right)(\operatorname{Im})_{\mathrm{d}}$ & - & $2969,2934,2874$ & $953,879,855,811,777$ & 1550 & 1476,1418 & 74,132 \\
\hline $\mathrm{Zn}\left(\mathrm{L}_{2}\right)_{2}(\mathrm{Im}) \cdot \mathrm{H}_{2} \mathrm{O}$ & 3122,3037 & $2973,2941,2873$ & $\begin{array}{c}953,906,880,823,812, \\
777,767\end{array}$ & 1542 & 1467,1408 & 75,134 \\
\hline
\end{tabular}

\subsection{Thermogravimetric Studies in Air}

3.3.1. Thermolysis of M(II) Formate Complexes with Imidazole

Thermal properties have been studied using the TG-DTG method under air atmosphere. All eight compounds are stable at room temperature and decompose gradually when heated.

Thermolysis of $\mathrm{Co}\left(\mathrm{L}_{1}\right)_{2}(\mathrm{Im}) \cdot \mathrm{H}_{2} \mathrm{O}$ begins at $50{ }^{\circ} \mathrm{C}$ (Figure $5 \mathrm{a}$, Table 4 ). First step of decomposition is dehydration (mass loss: found. $8.0 \%$; calc. $7.67 \%$ ). In the temperature range $170-280^{\circ} \mathrm{C}$ we observe partial thermolysis of imidazole molecule (mass loss: found. $21.5 \%$; calc. $21.72 \%$ ). Horizontal mass appears at $450{ }^{\circ} \mathrm{C}$ with $\mathrm{CoO}$ as a solid decomposition product (mass loss: found. $38.0 \%$; calc. $38.74 \%$ ).
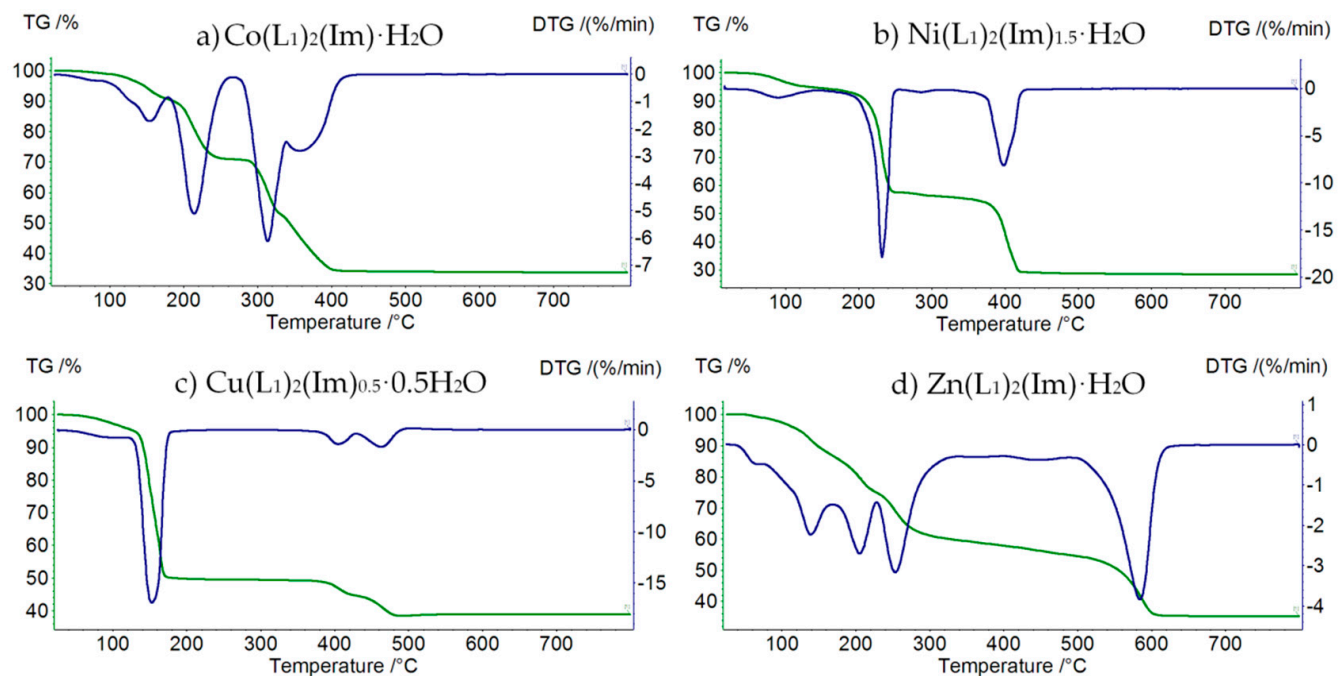

Figure 5. TG (green) and DTG (blue) curves of decomposition of: (a) $\mathrm{Co}\left(\mathrm{L}_{1}\right)_{2}(\mathrm{Im}) \cdot \mathrm{H}_{2} \mathrm{O}$, (b) $\mathrm{Ni}\left(\mathrm{L}_{1}\right)_{2}(\mathrm{Im})_{1.5} \cdot \mathrm{H}_{2} \mathrm{O}$, (c) $\mathrm{Cu}\left(\mathrm{L}_{1}\right)_{2}(\mathrm{Im})_{0.5} \cdot 0.5 \mathrm{H}_{2} \mathrm{O}$, and (d) $\mathrm{Zn}\left(\mathrm{L}_{1}\right)_{2}(\mathrm{Im}) \cdot \mathrm{H}_{2} \mathrm{O}$. 
Table 4. TG-DTG analysis data of decomposition of $\mathrm{Co}\left(\mathrm{L}_{1}\right)_{2}(\mathrm{Im}) \cdot \mathrm{H}_{2} \mathrm{O}$.

\begin{tabular}{ccccc}
\hline \multirow{2}{*}{$\begin{array}{c}\text { Compound/Solid } \\
\text { Intermediate }\end{array}$} & $\begin{array}{c}\text { Temperature } \\
\text { Range, }\left[{ }^{\circ} \mathrm{C}\right]\end{array}$ & \multicolumn{2}{c}{ Mass Loss, [\%] } & \multirow{2}{*}{$\begin{array}{c}\text { Solid Intermediate/Final } \\
\text { Residue }\end{array}$} \\
\cline { 3 - 4 } & $50-170$ & Found & Calculated & \\
\hline $\mathrm{Co}\left(\mathrm{L}_{1}\right)_{2}(\mathrm{Im}) \cdot \mathrm{H}_{2} \mathrm{O}$ & $170-280$ & 21.5 & 7.67 & $\mathrm{Co}\left(\mathrm{L}_{1}\right)_{2}(\mathrm{Im})$ \\
\hline $\mathrm{Co}\left(\mathrm{L}_{1}\right)_{2}(\mathrm{Im})$ & $280-700$ & 38.0 & 38.74 & $\mathrm{Co}\left(\mathrm{L}_{1}\right)_{2}(\mathrm{Im})_{0.25}$ \\
\hline $\mathrm{Co}\left(\mathrm{L}_{1}\right)_{2}(\mathrm{Im})_{0.25}$ & & $\mathrm{CoO}$ \\
\hline
\end{tabular}

$\mathrm{Ni}\left(\mathrm{L}_{1}\right)_{2}(\mathrm{Im})_{1.5} \cdot \mathrm{H}_{2} \mathrm{O}$ is thermally stable up to $50{ }^{\circ} \mathrm{C}$ (Figure $5 \mathrm{~b}$, Table 5). In the first step a water molecule is released (mass loss: found. $6.0 \%$; calc. $6.70 \%$ ). Above $170{ }^{\circ} \mathrm{C}$, decomposition of imidazole begins (mass loss: found. $38.0 \%$; calc. $37.99 \%$ ). In the temperature range $310-600{ }^{\circ} \mathrm{C}$, the thermodestruction of formate ions takes place (mass loss: found. $27.0 \%$; calc. $27.54 \%$ ). The final product of decomposition is $\mathrm{NiO}$.

Table 5. TG-DTG analysis data of decomposition of $\mathrm{Ni}\left(\mathrm{L}_{1}\right)_{2}(\mathrm{Im})_{1.5} \cdot \mathrm{H}_{2} \mathrm{O}$.

\begin{tabular}{ccccc}
\hline \multirow{2}{*}{$\begin{array}{c}\text { Compound/Solid } \\
\text { Intermediate }\end{array}$} & $\begin{array}{c}\text { Temperature } \\
\text { Range, }\left[{ }^{\circ} \mathrm{C}\right]\end{array}$ & \multicolumn{2}{c}{ Mass Loss, [\%] } & \multirow{2}{*}{$\begin{array}{c}\text { Solid Intermediate/Final } \\
\text { Residue }\end{array}$} \\
\cline { 3 - 4 } & $50-170$ & 6.0 & 6.70 & $\mathrm{Ni}\left(\mathrm{L}_{1}\right)_{2}(\mathrm{Im})_{1.5}$ \\
\hline $\mathrm{Ni}\left(\mathrm{L}_{1}\right)_{2}(\mathrm{Im})_{1.5} \cdot \mathrm{H}_{2} \mathrm{O}$ & $170-310$ & 38.0 & 37.99 & $\mathrm{Ni}\left(\mathrm{L}_{1}\right)_{2}$ \\
\hline $\mathrm{Ni}\left(\mathrm{L}_{1}\right)_{2}(\mathrm{Im})_{1.5}$ & $310-600$ & 27.0 & 27.54 & $\mathrm{NiO}$ \\
\hline $\mathrm{Ni}\left(\mathrm{L}_{1}\right)_{2}$ & & & Calculated & \\
\hline
\end{tabular}

$\mathrm{Cu}\left(\mathrm{L}_{1}\right)_{2}(\mathrm{Im})_{0.5} \cdot 0.5 \mathrm{H}_{2} \mathrm{O}$ starts to decompose at $40{ }^{\circ} \mathrm{C}$ (Figure $5 \mathrm{c}$, Table 6). Additionally, in this case, the first step of decomposition is dehydration (mass loss: found. $5.0 \%$; calc. $4.58 \%$ ). In the temperature range $140-280{ }^{\circ} \mathrm{C}$, we observe the thermolysis of organic molecule, as well as partial decomposition of formate ions (mass loss: found. $46.0 \%$; calc. $45.93 \%$ ). In the temperature range $280-560{ }^{\circ} \mathrm{C}$, the total decomposition of formates takes place (mass loss: found. $9.5 \%$; calc. $9.03 \%$ ). Above $560{ }^{\circ} \mathrm{C}$, the horizontal mass for $\mathrm{CuO}$ appears.

Table 6. TG-DTG analysis data of decomposition of $\mathrm{Cu}\left(\mathrm{L}_{1}\right)_{2}(\mathrm{Im})_{0.5} \cdot 0.5 \mathrm{H}_{2} \mathrm{O}$.

\begin{tabular}{ccccc}
\hline \multirow{2}{*}{$\begin{array}{c}\text { Compound/Solid } \\
\text { Intermediate }\end{array}$} & $\begin{array}{c}\text { Temperature } \\
\text { Range, }\left[{ }^{\circ} \mathrm{C}\right]\end{array}$ & \multicolumn{2}{c}{ Mass Loss. [\%] } & \multirow{2}{*}{$\begin{array}{c}\text { Solid Intermediate/Final } \\
\text { Residue }\end{array}$} \\
\cline { 3 - 4 } & $40-140$ & Found & Calculated & \\
\hline $\mathrm{Cu}\left(\mathrm{L}_{1}\right)_{2}(\mathrm{Im})_{0.5} \cdot 0.5 \mathrm{H}_{2} \mathrm{O}$ & 5.0 & 4.58 & $\mathrm{Cu}\left(\mathrm{L}_{1}\right)_{2}(\mathrm{Im})_{0.5}$ \\
\hline $\mathrm{Cu}\left(\mathrm{L}_{1}\right)_{2}(\mathrm{Im})_{0.5}$ & $140-280$ & 46.0 & 45.93 & $\mathrm{Cu}\left(\mathrm{L}_{1}\right)_{0.75}$ \\
\hline $\mathrm{Cu}\left(\mathrm{L}_{1}\right)_{0.75}$ & $280-560$ & 9.5 & 9.03 & $\mathrm{CuO}$ \\
\hline
\end{tabular}

First step of decomposition of the $\mathrm{Zn}\left(\mathrm{L}_{1}\right)_{2}(\mathrm{Im}) \cdot \mathrm{H}_{2} \mathrm{O}$ compound (Figure $5 \mathrm{~d}$, Table 7) is dehydration connected with the decomposition of the imidazole molecule in the temperature range $50-270{ }^{\circ} \mathrm{C}$ (mass loss: found. $6.0 \%$; calc. $6.70 \%$ ). In the temperature range 270-620 ${ }^{\circ} \mathrm{C}$, we observe the thermodesctruction of formate ions (mass loss: found. $30.0 \%$; calc. $30.65 \%$ ). The final product of decomposition is $\mathrm{ZnO}$.

Table 7. TG-DTG analysis data of decomposition of $\mathrm{Zn}\left(\mathrm{L}_{1}\right)_{2}(\mathrm{Im}) \cdot \mathrm{H}_{2} \mathrm{O}$.

\begin{tabular}{ccccc}
\hline \multirow{2}{*}{$\begin{array}{c}\text { Compound/Solid } \\
\text { Intermediate }\end{array}$} & $\begin{array}{c}\text { Temperature } \\
\text { Range, }\left[{ }^{\circ} \mathrm{C}\right]\end{array}$ & Found & Calculated & \multirow{2}{\text{SolidIntermediate/Final}}{$\begin{array}{c}\text { Mass Loss. [\%] } \\
\text { Residue }\end{array}$} \\
\cline { 3 - 4 } $\mathrm{Zn}\left(\mathrm{L}_{1}\right)_{2}(\mathrm{Im}) \cdot \mathrm{H}_{2} \mathrm{O}$ & $50-270$ & 6.0 & 6.70 & $\mathrm{Zn}\left(\mathrm{L}_{1}\right)_{2}$ \\
\hline $\mathrm{Zn}\left(\mathrm{L}_{1}\right)_{2}$ & $270-620$ & 30.0 & 30.65 & $\mathrm{ZnO}$ \\
\hline
\end{tabular}

\subsubsection{Thermolysis of M(II) Propionate Complexes with Imidazole}

Decomposition of $\mathrm{Co}\left(\mathrm{L}_{2}\right)_{2}(\mathrm{Im}) \cdot \mathrm{H}_{2} \mathrm{O}$ starts at $40{ }^{\circ} \mathrm{C}$ (Figure 6a, Table 8). At this temperature, a water molecule is released (mass loss: found. $5.0 \%$; calc. $6.19 \%$ ). In the temperature 
range $140-330{ }^{\circ} \mathrm{C}$, the thermodestruction of the imidazole molecule takes place (mass loss: found. $23.0 \%$; calc. $23.38 \%$ ). In the next step, up to $440{ }^{\circ} \mathrm{C}$, we observe the destruction of propionate anions (mass loss: found. $42.0 \%$; calc. $41.95 \%$ ). Above $440{ }^{\circ} \mathrm{C}$, horizontal mass for $\mathrm{Co}_{2} \mathrm{O}_{3}$ appears.
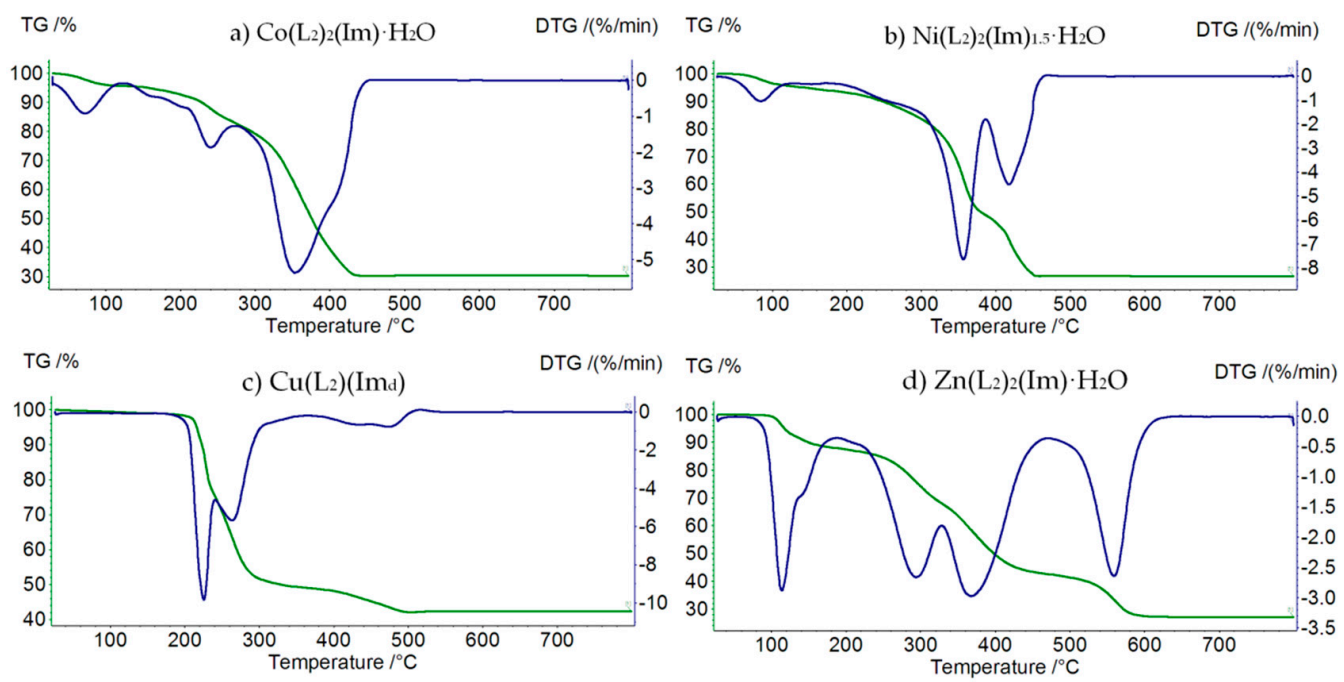

Figure 6. TG (green) and DTG (blue) curves of decomposition of: (a) $\mathrm{Co}\left(\mathrm{L}_{2}\right)_{2}(\mathrm{Im}) \cdot \mathrm{H}_{2} \mathrm{O}$, (b) $\mathrm{Ni}\left(\mathrm{L}_{2}\right)_{2}(\operatorname{Im})_{1.5} \cdot \mathrm{H}_{2} \mathrm{O},(\mathbf{c}) \mathrm{Cu}\left(\mathrm{L}_{2}\right)\left(\operatorname{Im}_{\mathrm{d}}\right)$, and $(\mathbf{d}) \mathrm{Zn}\left(\mathrm{L}_{2}\right)_{2}(\operatorname{Im}) \cdot \mathrm{H}_{2} \mathrm{O}$.

Table 8. TG-DTG analysis data of decomposition of $\mathrm{Co}\left(\mathrm{L}_{2}\right)_{2}(\mathrm{Im}) \cdot \mathrm{H}_{2} \mathrm{O}$.

\begin{tabular}{ccccc}
\hline $\begin{array}{c}\text { Compound/Solid } \\
\text { Intermediate }\end{array}$ & $\begin{array}{c}\text { Temperature } \\
\text { Range, }\left[{ }^{\circ} \mathrm{C}\right]\end{array}$ & Mass Loss. [\%] & $\begin{array}{c}\text { Solid Intermediate/Final } \\
\text { Residue }\end{array}$ \\
\cline { 1 - 3 } $\mathrm{Co}\left(\mathrm{L}_{2}\right)_{2}(\mathrm{Im}) \cdot \mathrm{H}_{2} \mathrm{O}$ & $40-120$ & 5.0 & 6.19 & $\mathrm{Co}\left(\mathrm{L}_{2}\right)_{2}(\mathrm{Im})$ \\
\hline $\mathrm{Co}\left(\mathrm{L}_{2}\right)_{2}(\mathrm{Im})$ & $140-330$ & 23.0 & 23.38 & $\mathrm{Co}_{2}\left(\mathrm{~L}_{2}\right)_{2}$ \\
\hline $\mathrm{Co}\left(\mathrm{L}_{2}\right)_{2}$ & $330-440$ & 42.0 & 41.95 & $\mathrm{Co}_{2} \mathrm{O}_{3}$ \\
\hline
\end{tabular}

$\mathrm{Ni}\left(\mathrm{L}_{2}\right)_{2}(\mathrm{Im})_{1.5} \cdot \mathrm{H}_{2} \mathrm{O}$ is thermally stable up to $60^{\circ} \mathrm{C}$ (Figure $6 \mathrm{~b}$, Table 9 ). Additionally, in this case, the first step of decomposition is dehydration (mass loss: found. $5.0 \%$; calc. 5.54\%). In the next step, in the temperature range $140-370^{\circ} \mathrm{C}$, we can observe the thermolysis of imidazole and partial thermolysis of propionate ions (mass loss: found. $42.5 \%$; calc. $42.67 \%$ ). In this case, the final product of decomposition is $\mathrm{Ni}_{2} \mathrm{O}_{3}$, formed in the final step (mass loss: found. $26.5 \%$; calc. $26.34 \%$ ).

Table 9. TG-DTG analysis data of decomposition of $\mathrm{Ni}\left(\mathrm{L}_{2}\right)_{2}(\mathrm{Im})_{1.5} \cdot \mathrm{H}_{2} \mathrm{O}$.

\begin{tabular}{|c|c|c|c|c|}
\hline \multirow{2}{*}{$\begin{array}{l}\text { Compound/Solid } \\
\text { Intermediate }\end{array}$} & \multirow{2}{*}{$\begin{array}{c}\text { Temperature } \\
\text { Range, }\left[{ }^{\circ} \mathrm{C}\right]\end{array}$} & \multicolumn{2}{|c|}{ Mass Loss. [\%] } & \multirow{2}{*}{$\begin{array}{c}\text { Solid Intermediate/Final } \\
\text { Residue }\end{array}$} \\
\hline & & Found & Calculated & \\
\hline $\mathrm{Ni}\left(\mathrm{L}_{2}\right)_{2}(\mathrm{Im})_{1.5} \cdot \mathrm{H}_{2} \mathrm{O}$ & $60-140$ & 5.0 & 5.54 & $\mathrm{Ni}\left(\mathrm{L}_{2}\right)_{2}(\mathrm{Im})_{1.5}$ \\
\hline $\mathrm{Ni}\left(\mathrm{L}_{2}\right)_{2}(\mathrm{Im})_{1.5}$ & $140-370$ & 42.5 & 42.67 & $\mathrm{Ni}\left(\mathrm{L}_{2}\right)_{1.5}$ \\
\hline $\mathrm{Ni}\left(\mathrm{L}_{2}\right)_{1.5}$ & $370-560$ & 26.5 & 26.34 & $\mathrm{Ni}_{2} \mathrm{O}_{3}$ \\
\hline
\end{tabular}

Decomposition of $\mathrm{Cu}\left(\mathrm{L}_{2}\right)\left(\mathrm{Im}_{\mathrm{d}}\right)$ begins at $160{ }^{\circ} \mathrm{C}$ (Figure 6c, Table 10). In the temperature range $160-340{ }^{\circ} \mathrm{C}$, the total thermodestruction of imidazole and partial thermodestruction of propionate anions occurs (mass loss: found. $49.5 \%$; calc. $50.86 \%$ ). Above $340{ }^{\circ} \mathrm{C}$, we observe the total decomposition of propionate anions (mass loss: found. $9.0 \%$; calc. $10.27 \%$ ). This process stops at $540{ }^{\circ} \mathrm{C}$, when the final solid product of decomposition is formed-CuO. 
Table 10. TG-DTG analysis data of decomposition of $\mathrm{Cu}\left(\mathrm{L}_{2}\right)\left(\mathrm{Im}_{\mathrm{d}}\right)$.

\begin{tabular}{ccccc}
\hline \multirow{2}{*}{$\begin{array}{c}\text { Compound/Solid } \\
\text { Intermediate }\end{array}$} & $\begin{array}{c}\text { Temperature } \\
\text { Range, }\left[{ }^{\circ} \mathrm{C}\right]\end{array}$ & \multicolumn{2}{c}{ Mass Loss. [\%] } & \multirow{2}{*}{$\begin{array}{c}\text { Solid Intermediate/Final } \\
\text { Residue }\end{array}$} \\
\cline { 3 - 4 } & $160-340$ & Found & Calculated & \\
\hline $\mathrm{Cu}\left(\mathrm{L}_{2}\right)\left(\mathrm{Im}_{\mathrm{d}}\right)$ & $340-540$ & 99.5 & 50.86 & $\mathrm{Cu}\left(\mathrm{L}_{2}\right)_{0.5}$ \\
\hline $\mathrm{Cu}\left(\mathrm{L}_{2}\right)_{0.5}$ & 9.0 & 10.27 & $\mathrm{CuO}$ \\
\hline
\end{tabular}

In the case of $\mathrm{Zn}\left(\mathrm{L}_{2}\right)_{2}(\mathrm{Im}) \cdot \mathrm{H}_{2} \mathrm{O}$ (Figure $6 \mathrm{~d}$, Table 11), the first step of decomposition is dehydration, occurring at a temperature range of $80-130{ }^{\circ} \mathrm{C}$ (mass loss: found. $7.0 \%$; calc. $6.05 \%$ ). In the second step, up to $320{ }^{\circ} \mathrm{C}$, the imidazole molecule is released (mass loss: found. $23.0 \%$; calc. $22.88 \%$ ). The last step takes place in the temperature range $320-610{ }^{\circ} \mathrm{C}$ and is associated with the themodestruction of propionate anions (mass loss: found. $43.5 \%$; calc. $43.73 \%$ ). The final solid product of the thermolysis of this compound is $\mathrm{ZnO}$.

Table 11. TG-DTG analysis data of decomposition of $\mathrm{Zn}\left(\mathrm{L}_{2}\right)_{2}(\mathrm{Im}) \cdot \mathrm{H}_{2} \mathrm{O}$.

\begin{tabular}{|c|c|c|c|c|}
\hline \multirow{2}{*}{$\begin{array}{l}\text { Compound/Solid } \\
\text { Intermediate }\end{array}$} & \multirow{2}{*}{$\begin{array}{l}\text { Temperature } \\
\text { Range, }\left[{ }^{\circ} \mathrm{C}\right]\end{array}$} & \multicolumn{2}{|c|}{ Mass Loss. [\%] } & \multirow{2}{*}{$\begin{array}{c}\text { Solid Intermediate/Final } \\
\text { Residue }\end{array}$} \\
\hline & & Found & Calculated & \\
\hline $\mathrm{Zn}\left(\mathrm{L}_{2}\right)_{2}(\mathrm{Im}) \cdot \mathrm{H}_{2} \mathrm{O}$ & 80-130 & 7.0 & 6.05 & $\mathrm{Zn}\left(\mathrm{L}_{2}\right)_{2}(\mathrm{Im})$ \\
\hline $\mathrm{Zn}\left(\mathrm{L}_{2}\right)_{2}(\mathrm{Im})$ & $130-320$ & 23.0 & 22.88 & $\mathrm{Zn}\left(\mathrm{L}_{2}\right)_{2}$ \\
\hline $\mathrm{Zn}\left(\mathrm{L}_{2}\right)_{2}$ & $320-610$ & 43.5 & 43.73 & $\mathrm{ZnO}$ \\
\hline
\end{tabular}

\subsection{Catalytic Activity}

Figure 7 presents the scheme of the apparatus used for carrying out the reaction of styrene oxidation described in the Materials and Methods section.

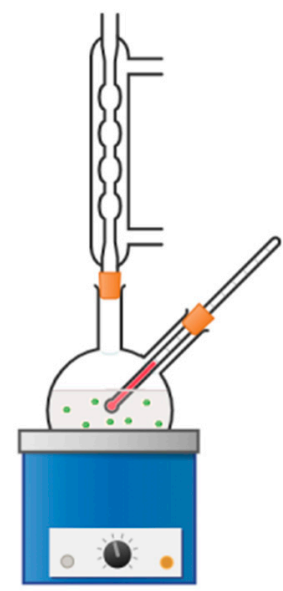

Figure 7. Scheme of the apparatus used for carrying out the reaction of styrene oxidation. The molar ratio of reagents was: $\mathrm{C}_{2} \mathrm{H}_{3} \mathrm{~N}: \mathrm{H}_{2} \mathrm{O}_{2}: \mathrm{C}_{8} \mathrm{H}_{8}=1: 1: 1$. After reaching $60^{\circ} \mathrm{C}, 10 \mathrm{mg}$ of the catalyst was added. Reaction was then carried out for $2 \mathrm{~h}$. After that time, samples for gas chromatography were probed.

Table 12 and Figure 8 present conversion degrees for eight described compounds (M(II) formate or propionate complexes with imidazole) as well as for four previously studied compounds [25] (M(II) acetate complexes with imidazole). In case of studied compounds, the main product of oxidation is carbon dioxide. 
Table 12. Conversion degrees for eight described compounds (M(II) formate or propionate complexes with imidazole) and for four previously studied compounds [25] (M(II) acetate complexes with imidazole).

\begin{tabular}{cc}
\hline Compound & Styrene Conversion Degree [\%] \\
\hline $\mathrm{Co}\left(\mathrm{L}_{1}\right)_{2}(\mathrm{Im}) \cdot \mathrm{H}_{2} \mathrm{O}$ & 12 \\
\hline $\mathrm{Ni}\left(\mathrm{L}_{1}\right)_{2}(\mathrm{Im})_{1.5} \cdot \mathrm{H}_{2} \mathrm{O}$ & 8 \\
\hline $\mathrm{Cu}\left(\mathrm{L}_{1}\right)_{2}(\mathrm{Im})_{0.5} \cdot 0.5 \mathrm{H}_{2} \mathrm{O}$ & 14 \\
\hline $\mathrm{Zn}\left(\mathrm{L}_{1}\right)_{2}(\mathrm{Im}) \cdot \mathrm{H}_{2} \mathrm{O}$ & 9 \\
\hline $\mathrm{Co}(\mathrm{Ac})_{2}(\mathrm{Im}) \cdot \mathrm{H}_{2} \mathrm{O}$ & 25 \\
\hline $\mathrm{Ni}(\mathrm{Ac})_{2}(\mathrm{Im})_{1.5} \cdot 2 \mathrm{H}_{2} \mathrm{O}$ & 12 \\
\hline $\mathrm{Cu}_{2}(\mathrm{Ac})_{4}(\mathrm{Im})$ & 21 \\
\hline $\mathrm{Zn}(\mathrm{Ac})_{2}(\mathrm{Im}) \cdot \mathrm{H}_{2} \mathrm{O}$ & 19 \\
\hline $\mathrm{Co}\left(\mathrm{L}_{2}\right)_{2}(\mathrm{Im}) \cdot \mathrm{H}_{2} \mathrm{O}$ & 14 \\
\hline $\mathrm{Ni}\left(\mathrm{L}_{2}\right)_{2}(\mathrm{Im})_{1.5} \cdot \mathrm{H}_{2} \mathrm{O}$ & 17 \\
\hline $\mathrm{Cu}\left(\mathrm{L}_{2}\right)\left(\mathrm{Im} \mathrm{d}_{\mathrm{d}}\right)$ & 24 \\
\hline $\mathrm{Zn}\left(\mathrm{L}_{2}\right)_{2}(\mathrm{Im}) \cdot \mathrm{H}_{2} \mathrm{O}$ & 24 \\
\hline &
\end{tabular}

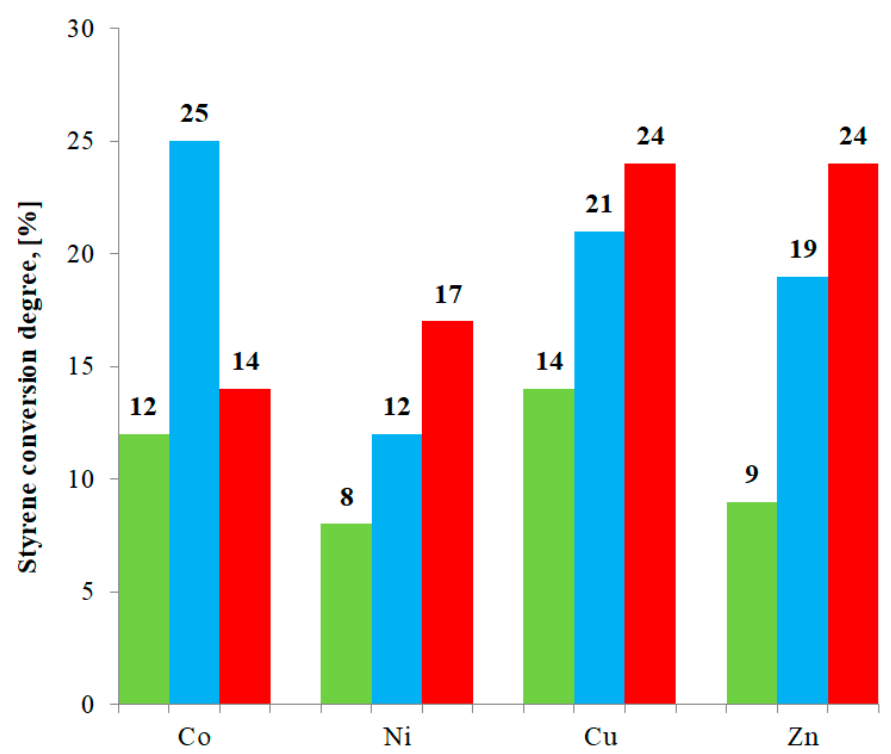

Figure 8. Styrene conversion degree for investigated compounds. Green bars: M(II) formateimidazole complexes; blue bars: Previously studied M(II) acetate-imidazole complexes [25]; and red bars: M(II) propionate-imidazole complexes.

\section{Conclusions}

In this work, we presented a synthesis procedure, as well as an investigation of properties of eight new compounds: $\mathrm{Co}\left(\mathrm{L}_{1}\right)_{2}(\mathrm{Im}) \cdot \mathrm{H}_{2} \mathrm{O}, \mathrm{Ni}\left(\mathrm{L}_{1}\right)_{2}(\mathrm{Im})_{1.5} \cdot \mathrm{H}_{2} \mathrm{O}, \mathrm{Cu}\left(\mathrm{L}_{1}\right)_{2}(\mathrm{Im})_{0.5} \cdot 0.5 \mathrm{H}_{2} \mathrm{O}$, $\mathrm{Zn}\left(\mathrm{L}_{1}\right)_{2}(\mathrm{Im}) \cdot \mathrm{H}_{2} \mathrm{O}, \mathrm{Co}\left(\mathrm{L}_{2}\right)_{2}(\mathrm{Im}) \cdot \mathrm{H}_{2} \mathrm{O}, \mathrm{Ni}\left(\mathrm{L}_{2}\right)_{2}(\mathrm{Im})_{1.5} \cdot \mathrm{H}_{2} \mathrm{O}$, and $\mathrm{Cu}\left(\mathrm{L}_{2}\right)(\mathrm{Im})_{\mathrm{d}}$ determine the way organic ligands bind metal centers. It also allowed us to confirm the deprotonation of an imidazole molecule in the case of a $\mathrm{Cu}\left(\mathrm{L}_{2}\right)(\mathrm{Im})_{\mathrm{d}}$ compound. All eight compounds form solids that are stable at room temperature and decompose gradually when heated. Taking into consideration the thermal stability of investigated compounds, we can say that the carbon chain length had very little effect on this aspect. In all cases, the solid products of decomposition are metal oxides. Of the eight synthesized compounds, $\mathrm{Cu}\left(\mathrm{L}_{2}\right)\left(\mathrm{Im}_{\mathrm{d}}\right)$ and $\mathrm{Zn}\left(\mathrm{L}_{2}\right)_{2}(\mathrm{Im}) \cdot \mathrm{H}_{2} \mathrm{O}$ exhibited the highest catalytic activity. In all cases, $\mathrm{M}(\mathrm{II})$ formateimidazole complexes showed the lowest activity. This study also allowed us to draw 
some valuable conclusions concerning the relationship between the carbon chain length and catalytic activity. For all $\mathrm{Ni}(\mathrm{II}), \mathrm{Cu}(\mathrm{II})$, and $\mathrm{Zn}(\mathrm{II})$ compounds, an increase of the carbon chain length went hand in hand with the increase of conversion degree. In case of $\mathrm{Co}(\mathrm{II})$ compounds, $\mathrm{Co}(\mathrm{Ac})_{2}(\mathrm{Im}) \cdot \mathrm{H}_{2} \mathrm{O}$ showed the highest activity. The remaining $\mathrm{Co}(\mathrm{II})$ compounds exhibited lower activity.

Author Contributions: Conceptualization, B.R. and A.C.; methodology, B.R., T.M. and A.C.; validation, B.R., R.C. and A.C.; formal analysis, B.R. and A.C.; investigation, B.R.; data curation, B.R.; writing-original draft preparation, B.R. and A.C.; writing-review and editing, B.R. and A.C.; visualization, B.R. and A.C.; supervision, A.C. All authors have read and agreed to the published version of the manuscript.

Funding: This research received no external funding.

Institutional Review Board Statement: Not applicable.

Informed Consent Statement: Not applicable.

Data Availability Statement: Not applicable.

Conflicts of Interest: The authors declare no conflict of interest.

\section{References}

1. Shalini, K.; Sharma, P.K.; Kumar, N. Imidazole and its biological activities: A review. Der. Chem. Sin. 2010, 1, 36-47.

2. Siwach, A.; Verma, P.K. Synthesis and therapeutic potential of imidazole containing compounds. BMC Chem. 2021, 15, 69. [CrossRef] [PubMed]

3. Gupta, V.; Kant, V. A Review on Biological Activity of Imidazole and Thiazole Moieties and their Derivatives. Sci. Int. 2013, 1, 253-260. [CrossRef]

4. De Luca, L. Naturally occurring and synthetic imidazoles: Their chemistry and their biological activities. Curr. Med. Chem. 2006, 13, 1-23.

5. Sharma, D.; Narasimhan, B.; Kumar, P.; Judge, V.; Narang, R.; De Clercq, E.; Balzarini, J. Synthesis, antimicrobial and antiviral evaluation of substituted imidazole derivatives. Eur. J. Med. Chem. 2009, 44, 2347-2353. [CrossRef]

6. Sharma, P.; LaRosa, C.; Antwi, J.; Govindarajan, R.; Werbovetz, K.A. Imidazoles as Potential Anticancer Agents: An Update on Recent Studies. Molecules. 2021, 26, 4213. [CrossRef]

7. Mlostoń, G.; Celeda, M.; Poper, W.; Kowalczyk, M.; Gach-Janczak, K.; Janecka, A.; Jasiński, M. Synthesis, Selected Transformations, and Biological Activity of Alkoxy Analogues of Lepidilines A and C. Materials 2020, 13, 4190. [CrossRef]

8. Gholami, Z.; Tišler, Z.; Rubáš, V. Recent advances in Fischer-Tropsch synthesis using cobalt-based catalysts: A review on supports, promoters, and reactors. Catal. Rev. 2021, 63, 512-595. [CrossRef]

9. Mirzaei, A.A.; Arsalanfar, M.; Bozorgzadeh, H.R.; Samimi, A. A review of Fischer-Tropsch synthesis on the cobalt based catalysts. Phys. Chem. Res. 2014, 2, 179-201. [CrossRef]

10. Zhou, H.; Song, J.; Fan, H.; Zhang, B.; Yang, Y.; Hu, J.; Zhu, Q.; Han, B. Cobalt catalysts: Very efficient for hydrogenation of biomass-derived ethyl levulinate to gammavalerolactone under mild conditions. Green Chem. 2014, 16, 3870. [CrossRef]

11. Zybert, M.; Tarka, A.; Mierzwa, B.; Raróg-Pilecka, W. Cobalt-lanthanum catalyst precursors for ammonia synthesis: Determination of calcination temperature and storage conditions. Pol. J. Chem. Tech. 2017, 19, 61-66. [CrossRef]

12. Izumi, Y.; Imaida, M.; Fukawa, H.; Akabori, S. Asymmetric Hydrogenation with Modified Raney Nickel. Studies on Modified Hydrogenation Catalyst. Bull. Chem. Soc. Jpn. 1963, 36, 155-160. [CrossRef]

13. Harada, T.; Izumi, Y. Improved modified Raney Nickel catalyst for enantioface-differentiating (asymmetric) hydrogenation of methyl acetoacetate. Chem. Lett. 1978, 7, 1195-1196. [CrossRef]

14. Studentschnig, A.F.H.; Schober, S.; Mittelbach, M. Conversion of Crude Palm Oil into Hydrocarbons over Commercial Raney Nickel. Energy Fuels 2013, 27, 7480-7484. [CrossRef]

15. Abudayyeh, A.M.; Schott, O.; Feltham, H.L.C.; Hanan, G.S.; Brooker, S. Copper catalysts for photo- and electro-catalytic hydrogen production. Inorg. Chem. Front. 2021, 8, 1015-1029. [CrossRef]

16. Bluhm, H.; Hävecker, M.; Knop-Gericke, A.; Kleimenov, E.; Schlogl, R. Methanol Oxidation on a Copper Catalyst Investigated Using in Situ X-ray Photoelectron Spectroscopy. J. Phys. Chem. B 2004, 108, 14340-14347. [CrossRef]

17. Górecka, S.; Pacultová, K.; Fridrichová, D.; Górecki, K.; Bílková, T.; Žebrák, R.; Obalová, L. Catalytic Oxidation of Ammonia over Cerium-Modified Copper Aluminium Zinc Mixed Oxides. Materials 2021, 14, 6581. [CrossRef] [PubMed]

18. Nisa, R.U.; Mahmood, T.; Ludwig, R.; Ayub, K. Theoretical mechanistic investigation of zinc(II) catalyzed oxidation of alcohols to aldehydes and esters. RSC Adv. 2016, 6, 31876-31883. [CrossRef]

19. Cheung, E.; Alberti, C.; Enthaler, S. Chemical Recycling of End-of-Life Poly(lactide) via Zinc-Catalyzed Depolymerization and Polymerization. ChemistryOpen 2020, 9, 1224-1228. [CrossRef] [PubMed] 
20. Adam, F.; Iqbal, A. The oxidation of styrene by chromium-silica heterogeneous catalyst prepared from rice husk. Chem. Eng. J. 2010, 160, 742-750. [CrossRef]

21. Kumar, S.B.; Mirajkar, S.P.; Pais, G.C.G.; Kumar, P.; Kumar, R. Epoxidation of Styrene over a Titanium Silicate Molecular Sieve TS1 Using Dilute $\mathrm{H}_{2} \mathrm{O}_{2}$ as Oxidizing Agent. J. Catal. 1995, 156, 163-166. [CrossRef]

22. Gao, D.; Gao, Q. Selective oxidation of styrene to benzaldehyde over VSB-5 and isomorphously substituted cobalt VSB-5. Catal. Commun. 2007, 8, 681-685. [CrossRef]

23. Aberkouks, A.; Mekkaoui, A.A.; Boualy, B.; El Houssame, S.; Ali, M.A.; El Firdoussi, L. Selective oxidation of styrene to benzaldehyde by $\mathrm{Co}-\mathrm{Ag}$ codoped $\mathrm{ZnO}$ catalyst and $\mathrm{H}_{2} \mathrm{O}_{2}$ as oxidant. Adv. Mater. Sci. Eng. 2018, 2018, 1-7. [CrossRef]

24. Titinchi, S.J.; VonWillingh, G.; Abbo, H.S.; Prasad, R. Tri- and tetradentate copper complexes: A comparative study on homogeneous and heterogeneous catalysis over oxidation reactions. Catal. Sci. Technol. 2015, 5, 325-338. [CrossRef]

25. Czylkowska, A.; Rogalewicz, B.; Raducka, A.; Błaszczyk, N.; Maniecki, T.; Wieczorek, K.; Mierczyński, P. Synthesis, Spectroscopic, Thermal and Catalytic Properties of Four New Metal (II) Complexes with Selected N- and O-Donor Ligands. Materials 2020, 13, 3217. [CrossRef]

26. Gueorguiev, G.K.; Pacheco, J.M. Shapes of cagelike metal carbide clusters: First-principles calculations. Phys. Rev. B 2003, 68, 241401(R). [CrossRef]

27. Dos Santos, R.B.; Rivelino, R.; de Brito Mota, F.; Gueorguiev, G.K.; Kakanakova-Georgieva, A. Dopant species with Al-Si and N-Si bonding in the MOCVD of AlN implementing trimethylaluminum, ammonia and silane. J. Phys. D Appl. Phys. 2015, $48,295104$. [CrossRef]

28. Tavares, S.R.; Vaiss, V.S.; Novais Antunes, F.P.; Fonseca, C.G.; Nangoi, I.M.; Moraes, P.I.R.; Soares, C.V.; Haddad, J.F.S.; Lima, L.L.; Silva, B.N.N.; et al. DFT calculations for structural prediction and applications of intercalated lamellar compounds. Dalton Trans. 2018, 47, 2852-2866. [CrossRef] [PubMed]

29. Nakamoto, K. Infrared and Raman Spectra of Inorganic and Coordination Compounds; John and Wiley and Sons: New York, NY, USA, 2009.

30. Alcock, N.W.; Tracy, V.M.; Waddington, T.C. Acetates and acetato-complexes. Part 2. Spectroscopic studies. J. Chem. Soc. Dalton Trans. 1976, 21, 2243-2246. [CrossRef] 